\title{
Heritage monitoring and surveillance using Sentinel satellite data in the Lower Alentejo (Portugal)
}

\author{
Steffan Davies, Martino Correia, Ricardo Cabral
}

\begin{abstract}
In this article, the potential of Satellite Remote Sensing (SRS) for large-scale monitoring of archaeological sites is analysed. This analysis focuses on the Portuguese Lower Alentejo region, where multiple sites have been destroyed over the last years, mainly due to intensive agriculture. The development of a surveillance system based on data from the Sentinel 1 and Sentinel 2 satellite constellations, named SENSEOS, had its pilot application in this region during the first half of 2019. In a vast region where authorities lacked the proper resources to timely detect events endangering the integrity of heritage sites, this system tried to overcome these issues. By using Synthetic Aperture Radar (SAR) and optical data, it was possible to detect such events through a technique labelled Normalized Difference Amplitude Index (NDAI). The identification of these changes on the surface, associated with potentially destructive events, contributed to minimize the damage and destruction of archaeological sites..
\end{abstract}

Keywords: sentinel, satellite remote sensing, heritage monitoring, archaeological site preservation, NDAl, amplitude index change detection, archaeology

\section{Monitorización y vigilancia del patrimonio utilizando datos de satélite Sentinel en el Bajo Alentejo (Portugal)}

Resumen: Se analiza el potencial de la teledetección satelital para monitoreo a gran escala de sitios arqueológicos. Este análisis se centra en la región portuguesa del Bajo Alentejo, donde se han destruido múltiples sitios en los últimos años debido a la agricultura intensiva. El desarrollo de un sistema de vigilancia basado en datos de las constelaciones de satélites Sentinel 1 y Sentinel 2, SENSEOS, tuvo su aplicación piloto en esta región durante el primer semestre de 2019. En una región donde las autoridades carecían de los recursos adecuados para detectar eventos a tiempo, poniendo en peligro la integridad de los sitios, este sistema intentó superar estos problemas. El uso de radar de apertura sintética (SAR) y datos ópticos permitió detectar eventos a través de una técnica denominada Índice de Diferencia Normalizada de Amplitud (NDAI), identificando cambios en la superficie asociados con eventos destructivos y minimizando la destrucción de los sitios arqueológicos.

Palabras clave: sentinel, teledetección por satélite, monitorización del património, preservación de sitios arqueológicos, NDAl, detección de cambio de índice de amplitud, arqueología

\section{Introduction}

This study was developed in the scope of a partnership between the Research Centre for Archaeology, Arts and Heritage Sciences of the University of Coimbra (CEAACP) and THEIA, a university spin-off company. The European Space Agency provided funding for this project through the Business Incubation Centre (ESA-BIC), with an incubation period at ESA-BIC Portugal between September 2017 and August 2019.The project resulted in the creation of a satellite monitoring and early warning system for archaeological heritage, called SENSEOS. The team has been developing the SENSEOS project as a pilot programme with two Portuguese public authorities, the Regional Department of Culture of Alentejo (DRCAlentejo), and the Regional Department of Culture of Algarve (DRCAlgarve), in order to assess the benefit of implementing an early warning system based on satellite remote sensing. The project has been monitoring 1396 archaeological sites in the Alentejo region, and 5 in Algarve. Every 6 days, all parties receive a report and, in the event of potential hazard, a risk map with observations or further interpretation is provided, if necessary. In order to share the results our data processing, SENSEOS project includes a WebGIS platform containing 
all the information, including archaeological site locations and their associated risk level.

The use of satellite remote sensing and Synthetic Aperture Radar (SAR) in the field of archaeology is not a recent phenomenon. While the technology is related to the popular Ground-penetrating Radar used widely in archaeology for non-invasive prospection (Conyers 2006), it differs in the fact that it offers a much larger field of view in exchange for image definition and visible features, while offering a much lower cost and completely remote approach. The first SRS studies applied to archaeology were published in the second half of the 1970s, and the first archaeological studies using SRS were published in the beginning of the 1980s, but the low resolution of the Landsat 1 satellite restricted their potential to the identification and study of paleolandscapes (Parcak 2009: 22). The same time period applies to the use of SAR systems in archaeological research, which were installed on aircraft and used for the study of anthropic landscapes where aerial photography proved to be unreliable (Adams, Brown, Culbert 1981). It was later during the 21st century that news applications of SRS applied to archaeology started to take form, in large part due to the increase in resolution of optical sensors such as Quickbird II, which allowed for an approach of SRS as a tool for archaeological prospection (Lasaponara \& Masini 2005) as the resolution slowly approached that of aerial photography. SRS as a tool for heritage conservation and protection is the most recent of SRS developments in archaeology, enabled by the use of very high-resolution SAR sensors. One example of such an approach was applied in the city of Homs in Syria, which analysed the damage to public infrastructure and heritage caused by the armed conflict in the area (Tapete et. al. 2015). The study presented in this article represents a continuation of this last approach of using SRS as a method of identifying and preventing damage to heritage sites.

The main area of interest for this study is the Alentejo region in the South of Portugal, focusing on the Lower Alentejo area. Alentejo has a geographical extension of $31,551.2 \mathrm{~km}^{2}$ corresponding to approximately one third of the country's landmass. It is also home to thousands of archaeological sites and features, with 1064 documented sites in the municipality of Beja alone. The landscape of the Alentejo region, of a rural and agricultural nature, has been changing at a rapid pace, due to the substitution of cereal based crops and dryland farming with intensive plantations of, mainly, olive and almond groves. New sources of water, supplied through the construction of dams and the Alqueva irrigation system, have enabled this process to take place (Morgado 2019). Despite the economic and agricultural benefits of this development, great concern has been placed on the possible consequences it might have on public health and the environment (Lusa 2019). The new availability of water for the purpose of irrigation has led to the introduction of more profitable crop species that require the intervention of highly mechanized procedures. The conversion of dryland fields into intensive olive and almond groves relies on the use of these types of mechanized invasive methods for soil revolution, involving practices such as deep ploughing. Traditional farming practices, which rely on the use of animals or light mechanized procedures, rarely disturb deep soil layers located at a depth of more than half a metre (Dunker et. al. 1994: 38). This means that most archaeological sites have remained relatively unharmed despite being located within agricultural fields and plantations. Now, with intense mechanization of agricultural practices, the continued existence of intact archaeological sites, many of which remain unexcavated, is under a serious threat. The large extension of numerous agricultural fields, combined with the lack of labour to supervise landscape transformation adequately in critical areas containing archaeological features, presents a serious problem. In order to give an appropriate response to this situation, it is necessary to develop a system capable of quickly identifying events that threaten cultural heritage. The synoptic view of satellite images, combined with short revisit times of the Sentinel satellite constellation, could provide a solution to this problem, and have great potential as tools for continuous monitoring of large areas of interest.

\section{Methodology}

This study employed Sentinel-1 Synthetic Aperture Radar and Sentinel-2 Multispectral Data. The main advantage of radar systems like Sentinel- 1 is the fact that they are capable of observing the Earth's surface in any type of weather conditions (Patel et. al., 2010, p. 244). Passive optical systems like Sentinel-2 provide information from multiple wavelengths but are highly vulnerable to clouds, which can make it impossible to view the surface under certain weather conditions. Sentinel-1's Synthetic Aperture Radar is an active sensor that provides its own source of illumination. This allows the satellite to produce an image based on its own light that returns to the sensor after being reflected from a target, in a process that is called backscatter. A number of different factors, such as surface morphology, surface characteristics, vegetation and soil humidity (Chen et. al., 2018, pp. 71-72), influence the intensity of the backscatter. Because agricultural practice affects all of these factors, it was hypothesized that radar data could serve as an indicator of agricultural activity in the proximity of archaeological sites. It would then be possible to use optical information as supporting data to extract further details whenever possible. The frequency of new satellite images, called revisit time, is 6 days for radar and approximately 5 days for optical data. All radar and optical data are derived from twin sister satellites (Sentinel-1A \& Sentinel-1B for radar, Sentinel-2A \& Sentinel2B for optical), which have identical equipment, ensuring compatibility of image products and avoiding secondary effects and bias seen when using different systems with different resolutions when calculating indexes (Obata et al. 2012a; Obata et al. 2012b). 
For this approach, we used a method we have referred to as NDAl, or Normalized Difference Amplitude Index. The way it functions is similar to the commonly used NDVI, or Normalized Difference Vegetation Index, widely employed in optical images since the 1990s (X. Zhang et al. 2006). The main difference is that instead of comparing the index between Red and Infrared pixel values (Carlson \& Ripley 1997: p. 241), we compare the intensity values of radar pixels between two different acquisition dates. For this approach, we relied on the open source software environments SNAP (Sentinel Application Platform) and QGIS (Quantum Geographic Information System). Using GRD (Ground Range Detected) Sentinel-1 products, the first step is to import the dataset into the SNAP environment and apply a pre-processing workflow to calibrate and correct the data. For this process we used a similar workflow to the one presented by F. Filiponi (2019), without the need to convert the product to $\mathrm{dB}$ (decibel) at the end of operations, and using the stack tool instead of DEM (Digital Elevation Model) assisted co-registration (spatial alignment) of image pixels. Through SNAP, we apply Precise Orbits to allow for high precision co-registration, remove Thermal Noise and Border Noise to eliminate artifacts and noise in the backscatter signal, Calibrate to Sigma Nought to correct for incidence angle variations in backscatter and standardize images across the stack, apply noise filtering using the Lee Sigma algorithm with the default parameters to reduce speckle, correct the product geometry using the Range-Doppler Terrain Correction to remove SAR geometric distortion, and stack the results using the Create Stack tool with the Initial Offset Method option set to Product Geolocation. Using the resulting stack of images, we apply the Band Math tool to produce the NDAI products (one for each polarisation) based on the following algorithm, where ImageB and ImageA refer to the oldest and most recent image, respectively:

$$
\left(\frac{(\text { Image } A-\text { ImageB })}{(\text { ImageA+ImageB })}\right)
$$

Optionally, and to reduce processing time in the GIS environment during the vectorisation procedure, it is advisable to filter out unwanted data through the Band Math Operator, using the following algorithm. Where $\mathrm{NDAl}_{\text {layer }}$ is the input NDAl product and $\mathrm{x}$ and $\mathrm{y}$ are the maximum and minimum desired values (such as -0.5 and 0.5), respectively:

$$
\text { (if } N D A l_{\text {layer }} \leq x V N D A I_{\text {layer }} \geq y \text { then } N D A l_{\text {layer }} \text { else } N a N \text { ) }
$$

This algorithm can be understood as: "if the input NDAI layer pixel is less or equal to $x$ or greater or equal to $y$, then preserve its value, otherwise reclassify as null". The result will filter out values regarded by the user as noise or unwanted data, which will be ignored by the vectorisation tool. The above formula reclassifies the NDAl input by maintaining pixel values that are below or equal to $\mathrm{x}$ or above or equal to $y$, and all the others in between are given a null value.
Using the Band Select tool, the NDAI products are separated from the stack and exported as GeoTIFF / BigTIFF format.

The NDAI GeoTIFF products can now be imported into QGIS. For manual inspection, the rasters are given a single band pseudocolor style based on discrete values (increments or decrements of 0.1 in a -1 to 1 range). For automated inspection, the NDAI rasters need to be reclassified based on a rules table (Table. 1) and vectorized to convert them into vector format. For reclassification, it was necessary to multiply NDAI values by 100 using the SNAP Band Math tool before exporting in order to transform the normalized values from float to integer format with two decimal places of precision (in QGIS 3.4, the GRASS 7 r.reclassify tool only worked properly with integer values). A rules table (table 1) was used to reclassify the image pixels to integer values ranging from 1 to 10 .

After this process, the image is simplified and it is possible to cross the areas of interest that are defined by some type of geometry (such as buffers) with the vectorized pixels of the NDAl processing using the Select by Location tool. The output will be based on the geometric predicate (Boolean criteria) the user defines in the selection process, which in this case would be the intersect predicate (returns TRUE if the intersection between vector features does not result in an empty set).

Table 1.- Example of a rules table used for reclassifying NDAI rasters into discrete values.

\begin{tabular}{|llllll|}
\hline & & & & & \\
-100 & thru & -90 & $=$ & 1 & Very High Loss \\
-90 & thru & -80 & $=$ & 2 & High Loss \\
-80 & thru & -70 & $=$ & 3 & Medium Loss \\
-70 & thru & -60 & $=$ & 4 & Low Loss \\
-60 & thru & -50 & $=$ & 5 & Very Low Loss \\
-50 & thru & 50 & $=$ & 6 & Noise \\
50 & thru & 60 & $=$ & 7 & Very Low Gain \\
60 & thru & 70 & $=$ & 8 & Low Gain \\
70 & thru & 80 & $=$ & 9 & Medium Gain \\
80 & thru & 90 & $=$ & 10 & High Gain \\
90 & thru & 100 & $=$ & 11 & Very High Gain \\
\hline
\end{tabular}

We normalized the data in order to allow us to work within the same ranges between different periods of observation, even if the degree of changes is different between image pairs. We filtered out a portion of the resulting data close to the value of zero (in an interval such as -0.5 and 0.5 ) in order to remove variations caused by noise or not very significant changes on the surface. This normalized data is subsequently categorized according to the severity of changes between image pairs, in order to allow the detection of different levels of changes in the landscape that could correspond to different kind of agricultural or physical events on the surface. Ploughing, for example, could produce a different pixel value compared to events 
such as irrigation or germination. In order to assess if surface change may have affected the archaeological sites, the information derived from the change detection processing is crossed with geographical information of archaeological sites in the area. A buffer is created around these sites in order to define a "sensitive area", and if the buffer crosses an area with identified changes, it is added to a selection along with all the other affected elements. These can then be extracted onto a layer and exported to be displayed on Google Earth or Google Maps.

\section{Results}

—Pisões

The archaeological site of Pisões is a partially excavated roman villa, containing a complex arrangement of structures of a domestic, agricultural a funerary nature, including four mausoleums (Pereira, Soares \& Soares 2013). The villa incorporates an advanced water supply, storage and distribution system which would have been necessary for the bathing and pool facilities, as well as the requirements for agricultural production (Serra 2008: 505). The site has suffered from a lack of maintenance that has led to its degradation over the years, despite its cultural importance (Dias 2017). Agricultural activity destroyed the unexcavated portion of the site, containing important features such as an aqueduct located underneath a water reservoir in a field to the Northeast, at an unknown date (Lemos 2018). To test our approach and to try to determine a time interval for these destructive events, a historical analysis was performed using archive imagery.

Observation of Sentinel 2 time series from 2017 shows that most of the surface transformations occurred during the second trimester of the year. Evidence that supports this observation includes the disappearance of the water reservoir in the Northeast of the excavated site, between the $5^{\text {th }}$ and $15^{\text {th }}$ of April 2017. This water reservoir was located in very close proximity to the roman aqueduct identified at the site. Clear images are not available from Sentinel-2 until the $15^{\text {th }}$ of May 2017. At this point, there seems to have been a unification of this field plot with another one adjacent to it in East-Northeast direction that had contained a small grove. These changes are indicators of possible preparation of land for future plantation.

For radar analysis, we applied NDAI processing to Sentinel- 1 satellite data. Pairs of images with a temporal baseline of approximately one month, beginning in 2014, were analysed. Of the changes verified in these images, the most intense correspond to an event of relatively high values between the 5 th of October and the $4^{\text {th }}$ of November 2017. Thereafter we processed the products chronologically situated between these two dates, with a temporal baseline of 6 days. Results show that the event occurred between the dates of 11 th and the $17^{\text {th }}$ of October 2017. Histograms of the output of NDAI processing corresponding to these dates [figure 1] show that values peak at or close to 0 , indicating good quality of inputs. The area corresponding to higher value NDAl pixels fits within the boundaries of the plot and shares the same shape [figure 2]. It is not known what happened during this time, but changes in other fields could indicate agricultural activity.

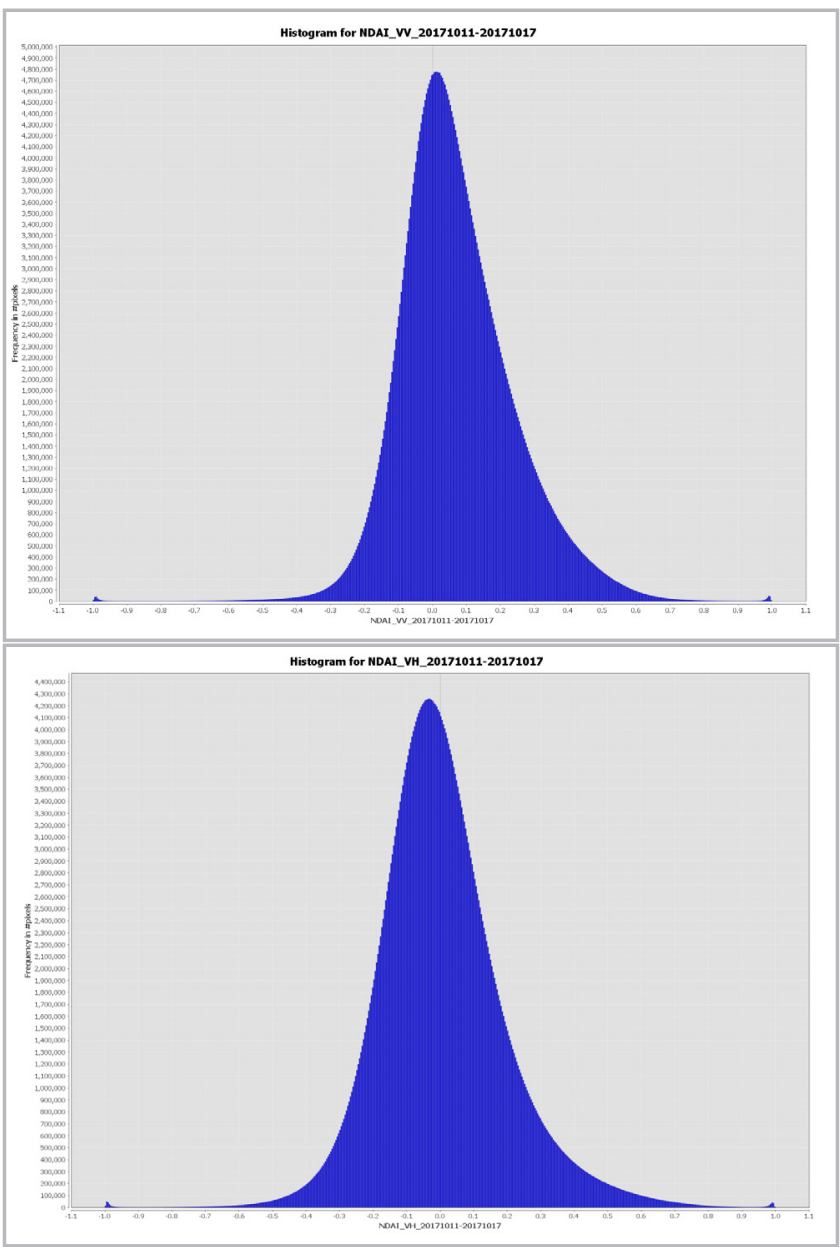

Figure 1.- NDAI Histogram for both polarizations (VV \& VH) representing pixel values and pixel frequency corresponding to the dates of 11 to 17 October 2019. They peak close to the value of 0 (no change in amplitude)..

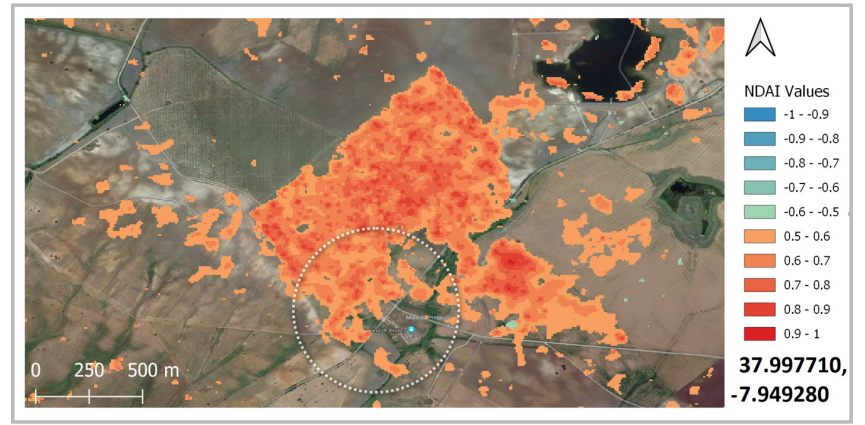

Figure 2.- Results of radar signal processing for Pisões, using NDAI change detection. Amplitude gain is shown as red, amplitude loss as blue. Archaeological context is within the circle. 


\section{Quinta do Estácio 10}

The site called Quinta do Estácio 10 is an archaeological context from the Roman period, located in Salvada e Quintos (Beja, Portugal). Archaeological trial trenching revealed a series of archaeological structures related to the transportation of water, as well as a concentration of archaeological materials, mostly ceramic building materials and pottery shards (Omniknos Arqueologia n.d).

Two Sentinel-1 images corresponding to the dates of the $15^{\text {th }}$ and $21^{\text {st }}$ of July 2019 were processed using the NDAI workflow. Histograms of NDAI results [figure 3] show that most values are equal or close to 0 , indicating good quality of both input images for each polarization. The results show evident patches in the field that encloses the archaeological site and also in the field immediately to the South [figure 4]. There is the possibility that some of these spots are present due to the buildings that exist adjacent to the paths. A person was dispatched to the location in order to confirm if these results

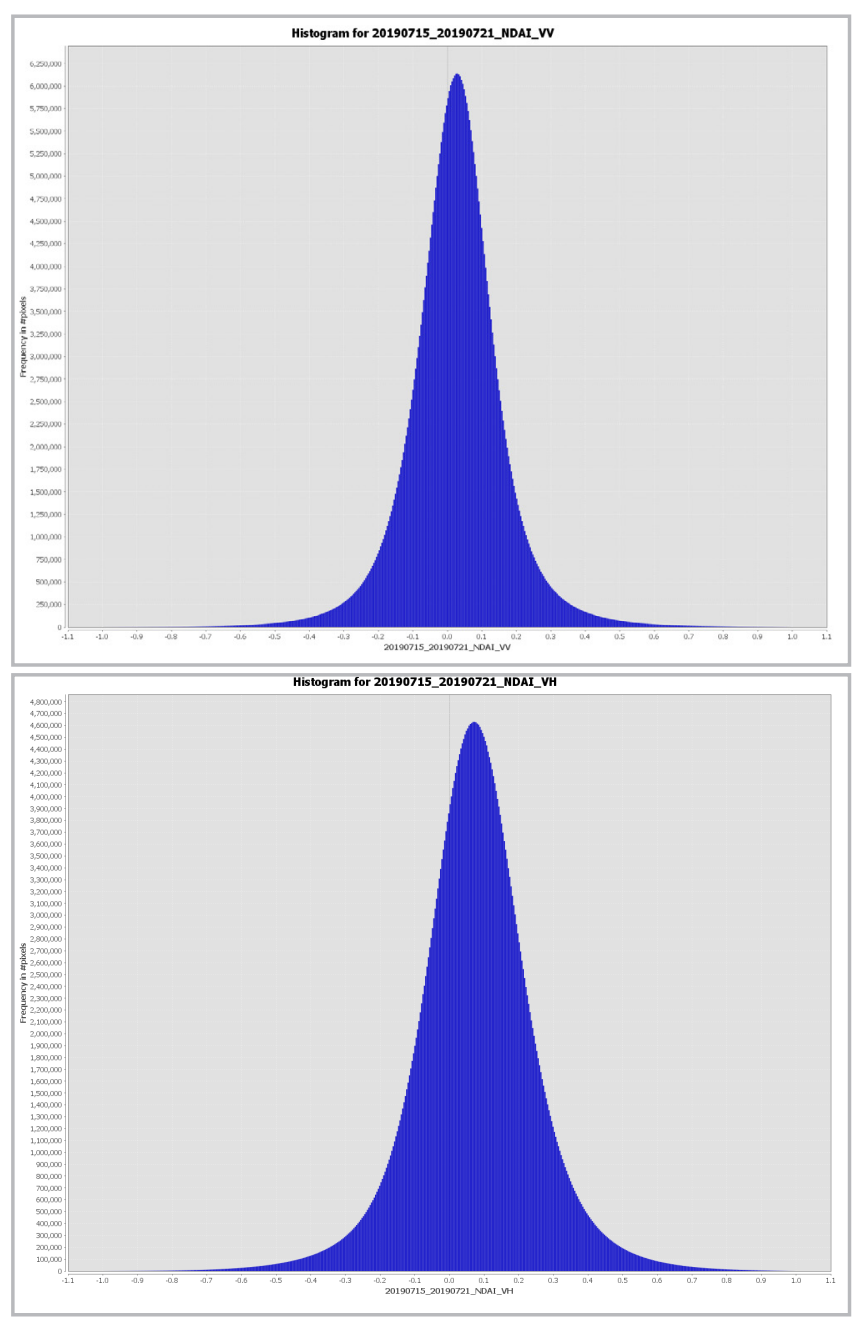

Figure 3.- NDAI Histogram for both polarizations (VV \& VH) representing frequency of pixel values corresponding to the date of 15 to 21 July 2019. They peak close to the value of 0 (no change in amplitude).

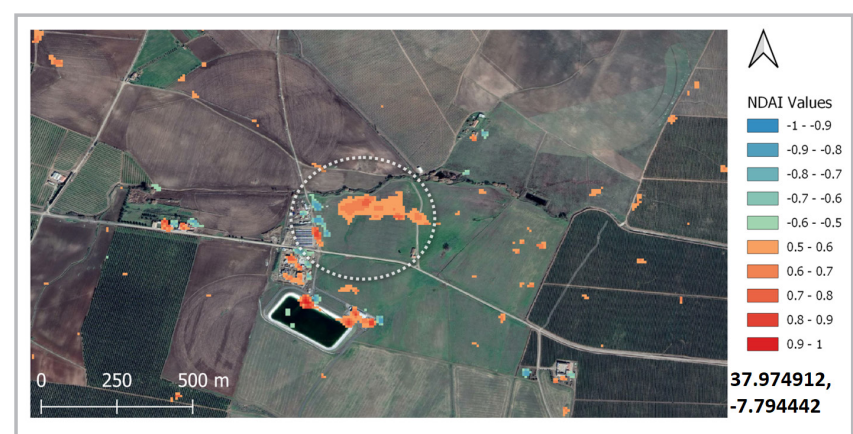

Figure 4.- Results of radar signal processing for Quinta do Estácio 10, using NDAl change detection. Amplitude gain is shown as red, amplitude loss as blue. Archaeological context is within the circle.

represented changes on the surface of the field where the archaeological site was located. Inspection of the site revealed intense soil mobilization including the opening of deep trenches in both perpendicular and parallel orientation in relation to the nearby river [figure 5]. Harrowing had also occurred on the site but its effects were superficial. The surplus soil that resulted from these activities was deposited in the field. Assessment of the location revealed damage to at least one of the foundations of the roman aqueduct.
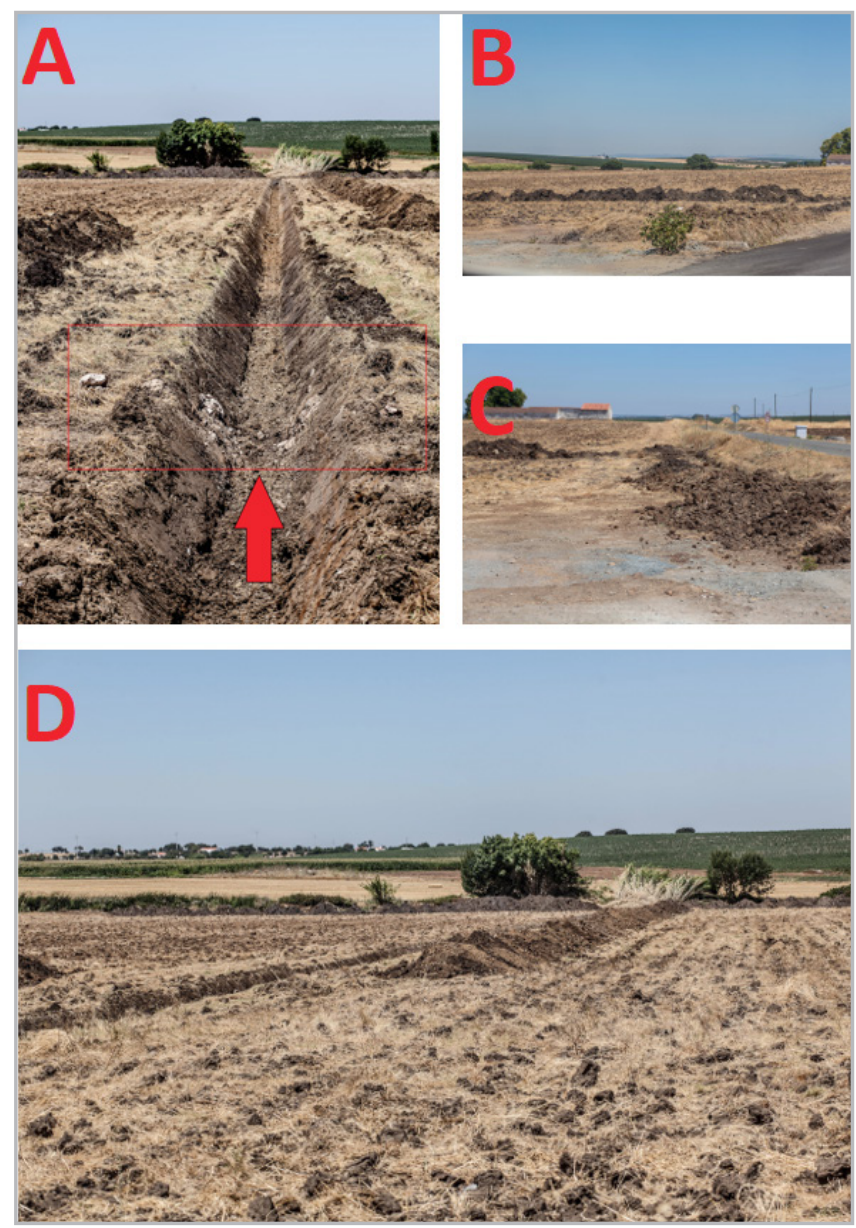

Figure 5.- Ground observation of the site of Quinta do Estácio 10. Photo A: Damage to archaeological features. Photo B, C, D: Different perspectives of the damage to the site 


\section{Conclusión}

This work highlights one of the main advantages of satellite data applied to Archaeology, which is the ability to perform large-scale territorial analysis and monitor destructive events on thousands of sites on a weekly basis, with a potentially global application. The results of these tests have validated the possibility of using satellite remote sensing data as a tool for monitoring archaeological sites. We believe, however, that it is necessary to use this approach in conjunction with local authorities for inspection and validation of results, in order to eliminate false positives and respond swiftly to destructive events before they affect heritage sites or before further damage is done. As such we recognize this approach as a tool to be used in articulation with additional means, in a wider comprehensive strategy for heritage protection. The main advantage of this methodology is the low cost for this type of service due to the free availability of Sentinel data, low operational costs associated with remote sensing processing, and the ability to use completely open source software for data processing. This is in contrast to traditional means of surveillance, with high logistical costs, derived from the extensive use of technicians on the ground when covering very large areas. The implementation of this technique will require cooperation with the entities responsible for archaeological conservation at a national or regional level, in order to have access to the databases containing the geographical positions of identified heritage sites and to ensure a swift and appropriate response to the identified occurrences. Future developments can include the incorporation of machine learning and automated cross-correlation of information from Sentinel-1 such as phase coherence, and Sentinel-2 such as NDVI (Normalized Difference Vegetation Index) or NDWI (Normalized Difference Water Index) in order to discard false positives and identify the nature of the changes that are visible with this type of approach.

\section{References}

ADAMS, R. E. W., BROWN, W. E., CULBERT, T. P. (1981). "Radar mapping, archaeology, and ancient Maya land use.", Science, 213(4515): 1457-1468.

CARLSON, T. N., RIPLEY, D. A. (1997). "On the relation between NDVI, fractional vegetation cover, and leaf area index", Remote sensing of Environment, 62(3): 241-252.

CHEN, F., YOU, J., TANG, P., ZHOU, W., MASINI, N., LASAPONARA, R. (2018). "Unique performance of spaceborne SAR remote sensing in cultural heritage applications: Overviews and perspectives", Archaeological Prospection, 25(1): 71-79. https://doi.org/10.1002/ arp.1591

CONYERS, L. B. (2006). "Ground-penetrating Radar for Archaeological Mapping", In: Wiseman J., El-Baz F. (eds) Remote Sensing in Archaeology. Interdisciplinary Contributions to Archaeology. Springer, New York, NY
DIAS, C. (2017). "Villa romana de Pisões é agora a luxuosa casa das ervas daninhas", Público, 17 July. https://www. publico.pt/2017/07/17/local/noticia/villa-romana-depisoes-foi-descoberta-ha-50-anos-e-esta-coberta-de-ervasdaninhas-1779095. [accessed: 25/10/2019].

DUNKER, R., VANCE, S., HOOKS, C., DARMODY, R. (1994). “Use of Cone Penetrometer Data to Evaluate Prime Farmland Rooting Media", Reclamation and Revegetation, 3: 38-47. http://doi. org/10.21000/JASMR94030038

FILIPPONI, F. (2019). "Sentinel-1 GRD Preprocessing Workflow", Proceedings, 18(1): 11. https://doi.org/10.3390/ECRS-3-06201

LASAPONARA, R., MASINI, N. (2005). "QuickBird-based analysis for the spatial characterization of archaeological sites: Case study of the Monte Serico medieval village", Geophysical Research Letters, 32(12).

LEMOS, N. (2018). "Zona envolvente à villa romana de Pisões terá sido fortemente afetada pela plantação de um olival intensivo", Diário do Alentejo, 29 January.

LUSA (2019). "Culturas intensivas no Alqueva geram receios que agricultores dizem infundados", RTPNotícias, 13 July. https://www.rtp.pt/noticias/economia/culturas-intensivas-noalqueva-geram-receios-que-agricultores-dizem-infundados n1160161. [accessed: 25/10/2019].

MORGADO, M. (2019). “Olival no Alentejo: a revolução agrária 4.0 à volta do Alqueva", Sapo, 24 February. https://24.sapo.pt/ economia/artigos/olival-no-alentejo-a-reforma-agraria-4-0-avolta-do-alqueva. [accessed: 25/10/2019].

OBATA, K., MIURA, T., YOSHIOKA, H. (2012). "Comparison of scaling effects in fraction of vegetation cover between algorithms based on linear mixture model using VI", 2012 IEEE International Geoscience and Remote Sensing Symposium: 1002-1005. https://doi.org/10.1109/IGARSS.2012.6350821

OBATA, K., MIURA, T., YOSHIOKA, H. (2012). "Analysis of the Scaling Effects in the Area-Averaged Fraction of Vegetation Cover Retrieved Using an NDVI-Isoline-Based Linear Mixture Model", Remote Sens, 4: 2156-2180. https://doi.org/10.3390/ $\underline{\text { rs4072156 }}$

OMNIKNOS ARQUEOLOGIA (n.d.). "Execução do Circuito Hidráulico Baleizão - Quintos e respetivos Blocos de Rega - Quinta do Estácio 10", Field Report. https://biblioteca. edia.pt/BiblioNET/Upload/PDFS/M03406.pdf [accessed: 25/10/2019]

PARCAK, S. H. (2009). Satellite remote sensing for archaeology. London \& New York: Routledge.

PATEL, V. M., EASLEY, G. R., HEALY JR, D. M., CHELLAPPA, R. (2010). "Compressed synthetic aperture radar", IEEE Journal of selected topics in signal processing, 4(2): 244-254. https://doi. org/10.1109/JSTSP.2009.2039181 
PEREIRA, C., SOARES, A.M.M., SOARES, R.M. (2013). “Os mausoléus da villa romana de Pisões: a morte no mundo rural romano", Revista Portuguesa de Arqueologia, 16: 303-321.

SERRA, M. (2008). "Novos dados para o conhecimento da Villa romana de Pisões (Beja)", Vipasca, 2: 503-507.

TAPETE, D., CIGNA, F., DONOGHUE, D.N. AND PHILIP, G. (2015). "Mapping changes and damages in areas of conflict: from archive C-band SAR data to new HR X-band imagery, towards the Sentinels", En Proceedings of FRINGE'15: Advances in the Science and Applications of SAR Interferometry and Sentinel-1 InSAR Workshop, Frascati, Italy, 23-27 March 2015, Ouwehand L., Ed., ESA Publication SP-731. https://doi.org/10.5270/Fringe2015.pp149

ZHANG, X., G. YAN, Q. LI, Z-L. LI, H. WAN, AND Z. GUO (2006), "Evaluating the fraction of vegetation cover based on NDVI spatial scale correction model.", International Journal of Remote Sensing, 27(24): 5359-5372. https://doi.org/10.1080/01431160600658107

\section{Author/s}

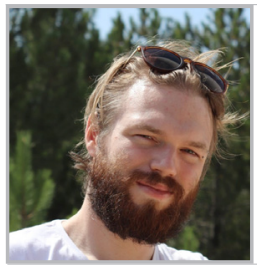

\author{
Steffan Clent Ap Davies \\ steffan@theia.pt \\ THEIA; CEAACP Coimbra, Portugal
}

Steffan Davies holds a Licentiate degree in Archaeology and a Master's degree in Archaeology and Territory, with a specialization in Archaeogeography, both by the University of Coimbra (Portugal). $\mathrm{He}$ is a researcher in the Centre of Studies in Archaeology, Arts and Heritage Sciences of the University of Coimbra (CEAACP), and is currently working at the Portuguese company THEIA in Research and Development, in fields such as Satellite Remote Sensing, Computer Programming., Virtual Reality and Digital Heritage.
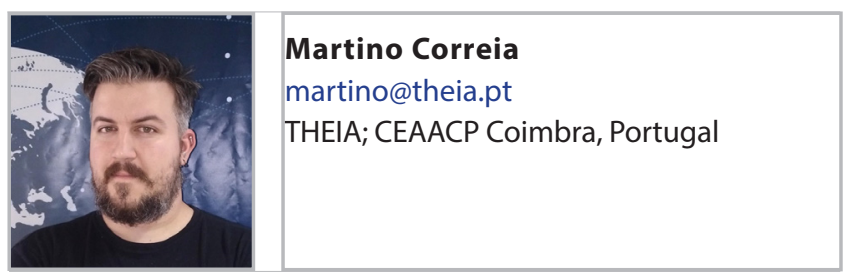

Martino Correia has graduate in "Archaeology and History" by the University of Coimbra (Portugal), with a Master's degree in "Archaeology and Territory" by the same University and a post-graduation in "European Heritage, Digital Media and the Information Society" carried out at the Universities of Coimbra and Salento (Lecce, Italy). He is a researcher in the Centre of Studies in Archaeology, Arts and Heritage Sciences of the University of Coimbra and was an Invited Assistant Professor at the Higher School of Education of Coimbra. He is also cofounder and managing-partner of the company THEIA, which works on the application of digital and technological solution to Archaeology and Cultural Heritage.

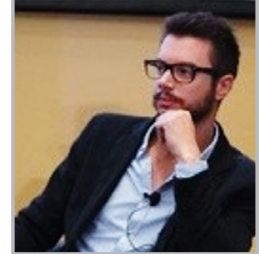

Ricardo Cabral

ricardo@theia.pt

THEIA; CEAACP Coimbra, Portugal

Ricardo Cabral holds a Licentiate Degree in Archaeology and History and is currently a PhD Candidate in Archaeology at the University of Coimbra. Between 2010 and 2019 he was an Invited Assistant Professor at the Faculty of Letters of the University of Coimbra. He is currently a researcher at the Centre of Studies in Archaeology, Arts and Heritage Sciences of the University of Coimbra, conducting research in Near Eastern Archaeology, where he coordinates the Kani Shaie Archaeological Project (Iraq) and participates in the Iraq Emergency Heritage Management Training Scheme, a British Museum project. He is also co-founder and managing-partner of the company THEIA, which works on the application of digital and technological solution to Archaeology and Cultural Heritage.

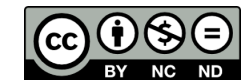

https://doi.org/10.37558/gec.v17i1.755 